\title{
The interrelation of the Russian Black Pied breed productive qualities of the Ural type depending on live weight
}

\author{
O.V. Gorelik ${ }^{1, *}$, O.P. Neverova ${ }^{1}, A . K$. Zharkenov $^{2}$, and $Y u . Y u$. Zharkenova $^{2}$ \\ ${ }^{1}$ Ural State Agricultural University, 42 Karl Liebknecht str., Yekaterinburg, 620075, Russian \\ Federation \\ ${ }^{2}$ Kostanay Industrial Pedagogical College, Kostanay, 110000, Kazakhstan
}

\begin{abstract}
Holsteinized Russian Black Pied cattle of the Ural type are bred in the Sverdlovsk region, which is represented by large, highly productive animals with a high genetic potential for productivity. The purpose of the work was to study the effect of first heifers' live weight on their productivity and the interrelation between milk yield and milk quality indicators. It was found that there was a positive tendency for an increase in milk yield with an increase in the cows' live weight from less than $550 \mathrm{~kg}$ to $624 \mathrm{~kg}$. The most significant increase in milk yield in cows was in the range from 574 to $599 \mathrm{~kg}$. The difference in milk yield between these groups was $692 \mathrm{~kg}$ or $8.1 \%$ in favor of animals with live weight of $575-599 \mathrm{~kg}$. An increase in cows' live weight over $625 \mathrm{~kg}$ leads to a decrease in milk yield, which amounted to $2.3 \%$. Changes in correlation are observed from a negative average value in cows with a live weight of less than $550 \mathrm{~kg}$ to a positive average value in cows with a live weight of more than $625 \mathrm{~kg}$. In first heifers with live weight from 575 to $599 \mathrm{~kg}$, a very low positive interrelation between live weight and milk yield per lactation was recorded (0.04).
\end{abstract}

\section{Introduction}

Increasing the production of animal origin food for a sustainable supply of the population with high-quality nutritious food is the main necessity in ensuring the health of the nation and food security of any country and the primary task of livestock workers [1-6]. At the same time, special attention is paid to the dairy cattle breeding development, since the main amount of more than $97 \%$ of the total production of a valuable food product and raw material for the dairy industry - milk, is obtained from cattle. Increasing cow productivity is inseparably associated with milk quality improvement [7-16]. The main livestock of dairy cattle is currently represented by the Russian Black Pied cattle and related breeds, including the Holstein breed having Dutch cattle roots. In recent years, the world gene pool of the best stud bulls of the Holstein breed has been widely used to improve domestic dairy cattle. Long-term holsteinization led to the creation of a large holsteinized cattle array in various climatic and ecological-forage zones, which differs in economically useful and biological characteristics

\footnotetext{
* Corresponding author: olgao205en@yandex.ru
} 
due to the cattle breed resources in the breeding zone and the origin country of stud bulls involved in crossing [17-21]. So, in the Sverdlovsk region, the Russian Black Pied cattle breeding stock of the Ural offspring was inseminated with Holstein breed stud bulls' seed of Canadian, Danish and German selection. As a result, large, highly productive animals with a high genetic productivity potential and well adapted to industrial milk production were obtained. They are able to show good average daily milk yield during the entire lactation, to produce for a long time without a sharp decrease in milk yield; however, a decrease in reproductive capacity is noted [22-24]. The influence study on the productive qualities of first heifers' live weight and the interrelation of productive traits with each other is relevant and of practical importance.

The purpose of the work was to study the effect of first heifers' live weight on their productivity and the interrelation between milk yield and milk quality indicators.

\section{Materials and methods}

The studies were carried out under the conditions of one of the pedigree reproducers for breeding holsteinized Russian Black Pied cattle of the Ural type. The study included all the first heifers' livestock who completed lactation as of 01.10 .2019 , which were divided into groups by live weight: up to $550 \mathrm{~kg}, 550-574 \mathrm{~kg}, 575-599 \mathrm{~kg}, 600-624 \mathrm{~kg}$ and over $625 \mathrm{~kg}$. For the analysis, the data of zootechnical and pedigree registration of the Seleks base were used. The first heifers' milk productivity was considered by carrying out control milking once a month; quality indicators of milk were MFF and MFP in milk, which were checked monthly from each cow in the conditions of the OJSC "Uralplemcenter" dairy laboratory of the Sverdlovsk region. The coefficient of milkiness, the amount of milk fat and milk protein, the correlation coefficients were calculated between milk yield and milk quality indicators; MFF and MFP in milk considering live weight.

\section{Results and Discussion}

The farm is engaged in breeding highly productive holsteinized Russian Black Pied cattle of the Ural type with a high thorough-bredness proportion of Holstein breed (more than 91\%). The number of cows was 1100 heads, including 273 first heifers (24.8\%) with an average productivity of $8702 \mathrm{~kg}$ in 2019 .

Figure 1 presents data on the productivity of first heifers in relation to live weight. 


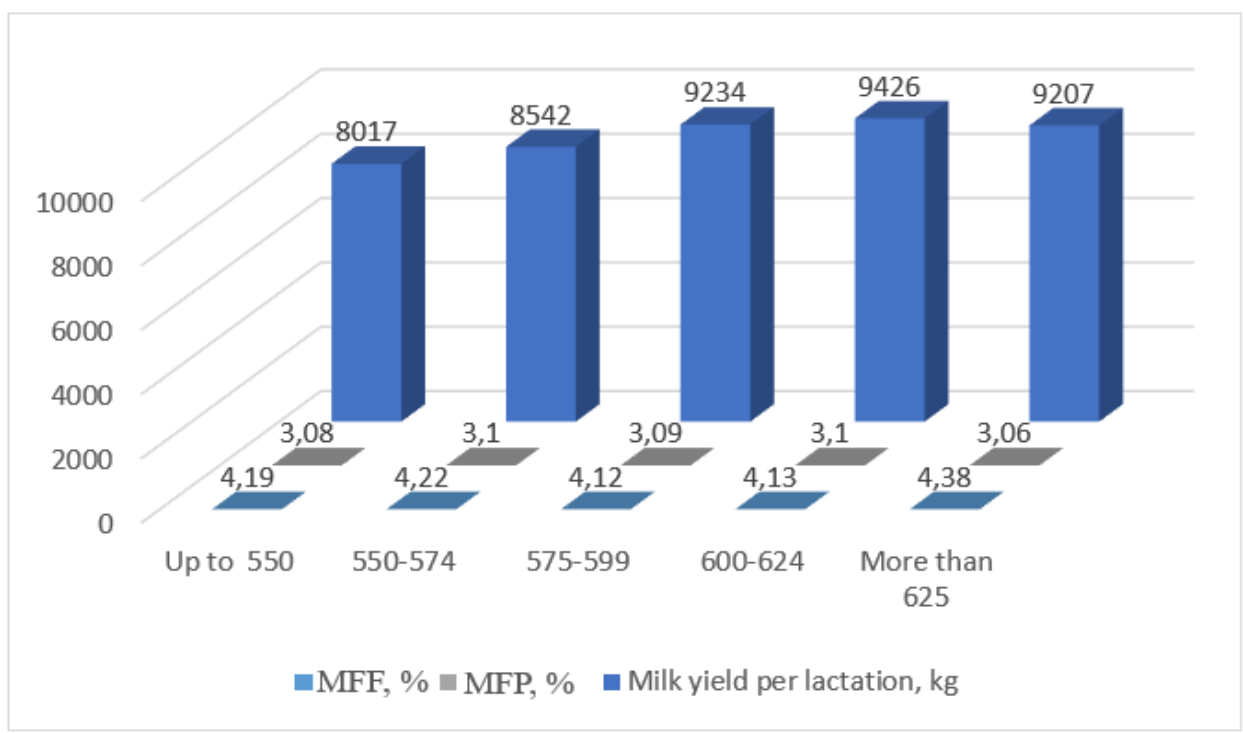

Fig. 1. Milk yield and quality indicators of cow milk.

The figure shows that there was a positive tendency for an increase in milk yield with an increase in the cows' live weight from less than $550 \mathrm{~kg}$ to $624 \mathrm{~kg}$. A higher live weight of animals was associated with an insignificant, but a decrease in milk yield in 305 days of lactation.

The most significant increase in milk yield in cows was in the range from 574 to $599 \mathrm{~kg}$. The difference in milk yield between these groups was $692 \mathrm{~kg}$ or $8.1 \%$ in favor of animals with live weight of 575-599 kg. An increase in live weight from $550 \mathrm{~kg}$ or less to $574 \mathrm{~kg}$ led to an increase in milk yield by $525 \mathrm{~kg}$ or $6.5 \%$. With an increase in live weight from 599 to $600-624 \mathrm{~kg}$, milk yield increased by $192 \mathrm{~kg}$ or $2.1 \%$. A decrease in milk yield was observed with further increase in cows' live weight, which amounted to $2.3 \%$.

The quality indicators of milk MFF and MFP varied depending on the milk yield and live weight of cows. With an increase in milk yield, there was a decrease in milk MFF. With an increase in live weight over $625 \mathrm{~kg}$, milk MFF increased sharply by $0.16-0.26 \%$ relative to other animals with a simultaneous decrease in milk BFP. The protein content of cow milk fluctuated slightly.

The calculation of the correlation coefficients between live weight and milk yield per lactation showed that depending on the cow weight, they changed from positive to negative, which allows to conclude that it is difficult to plan selection and breeding activities on the farm to increase milk yield through the use of larger animals (figure 2). 


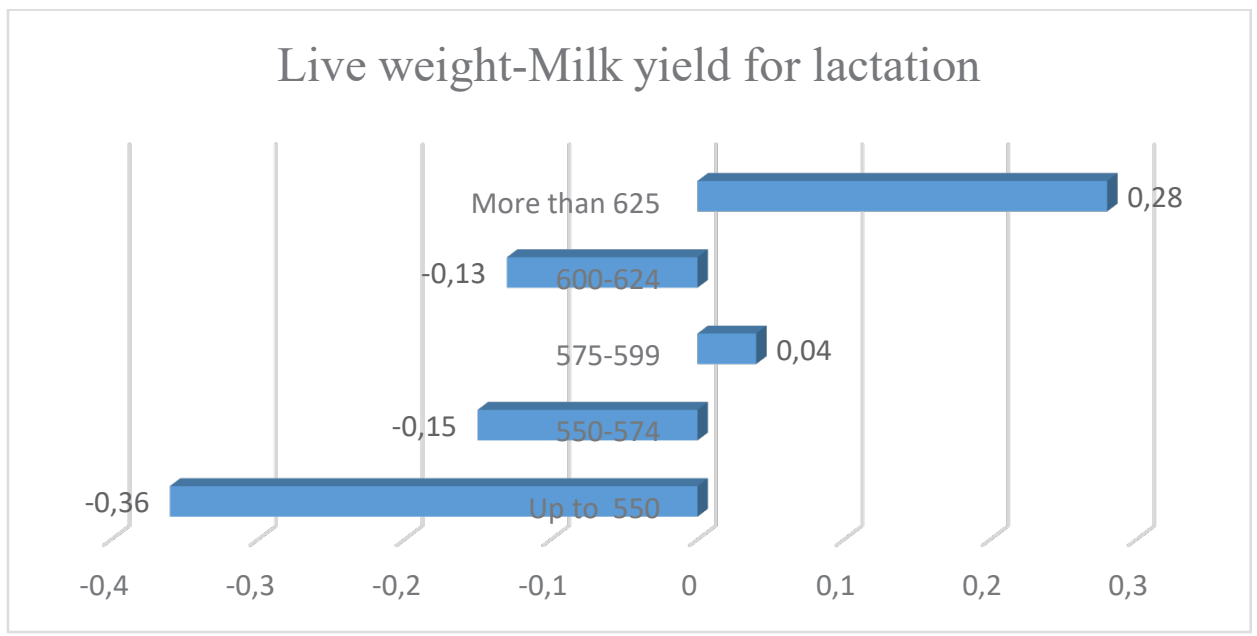

Fig. 2. The correlation of live weight with milk yield for lactation.

Changes in correlation are observed from a negative average value in cows with a live weight of less than $550 \mathrm{~kg}$ to a positive average value in cows with a live weight of more than $625 \mathrm{~kg}$. In first heifers with live weight from 575 to $599 \mathrm{~kg}$, a very low positive interrelation between live weight and milk yield per lactation was recorded (0.04).

Thus, despite the positive effect of the live weight increase to milk yield in absolute terms in this herd, the interrelation between these traits was negative, and an increase in live weight over $625 \mathrm{~kg}$ led to a decrease in milk yield (correlation coefficient 0.28 ).

Correlation coefficients between live weight and qualitative milk indicators also ranged from high positive to low negative (figure 3 ).

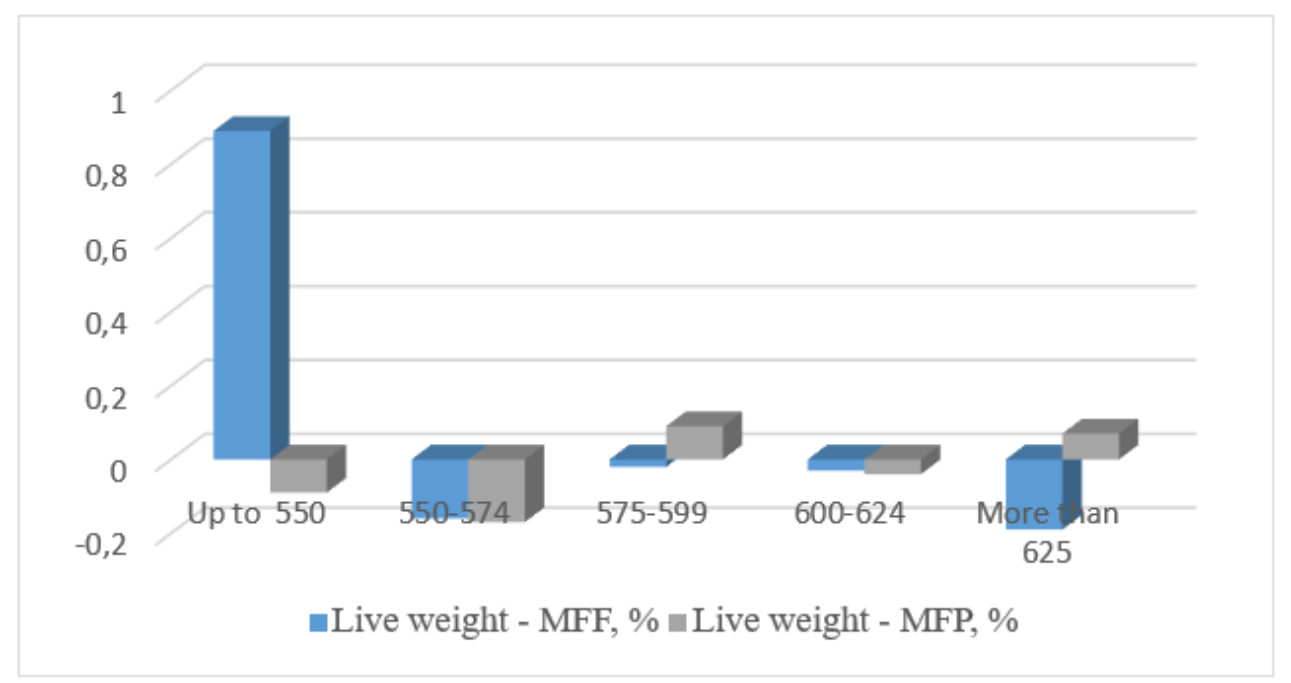

Fig. 3. Correlation coefficients between live weight and milk quality indicators.

No logical interrelation has been established between the live weight of cows and their milk quality indicators. Basically, the traits' correlation was low negative. In the group of first heifers with low live weight, a high positive interrelation for milk MFF was noted, which is most likely explained by the individual properties of the animals in the group. The positive 
correlation between live weight and MFP in milk in individual groups is also determined by the individual properties of first heifers.

Regardless of animals' live weight, the interrelation between milk yield and milk quality indicators in groups obeyed a general pattern (figure 4.).

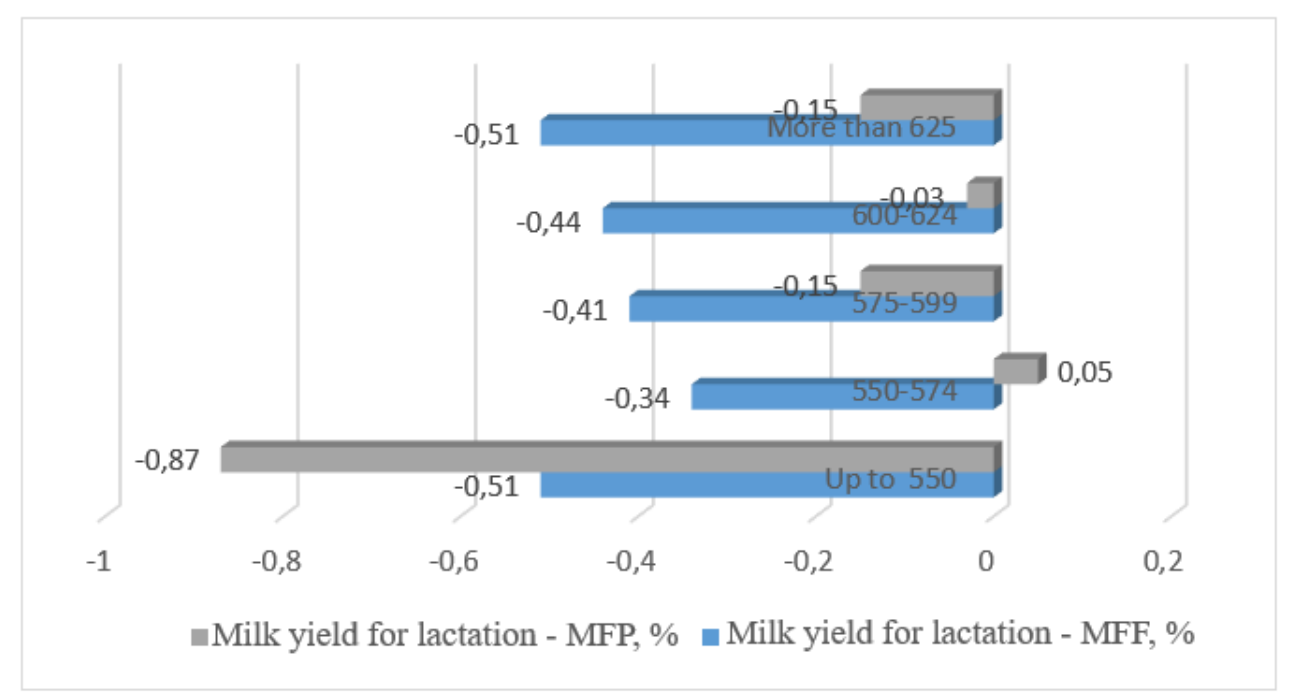

Fig. 4. Milk yield for first heifers' lactation and age of first insemination.

The increase in milk yield negatively correlated with the quality indicators of milk. With their increase, a decrease in MFF and MFP in milk was observed. A positive correlation was established for the quality indicators of milk (figure 5).

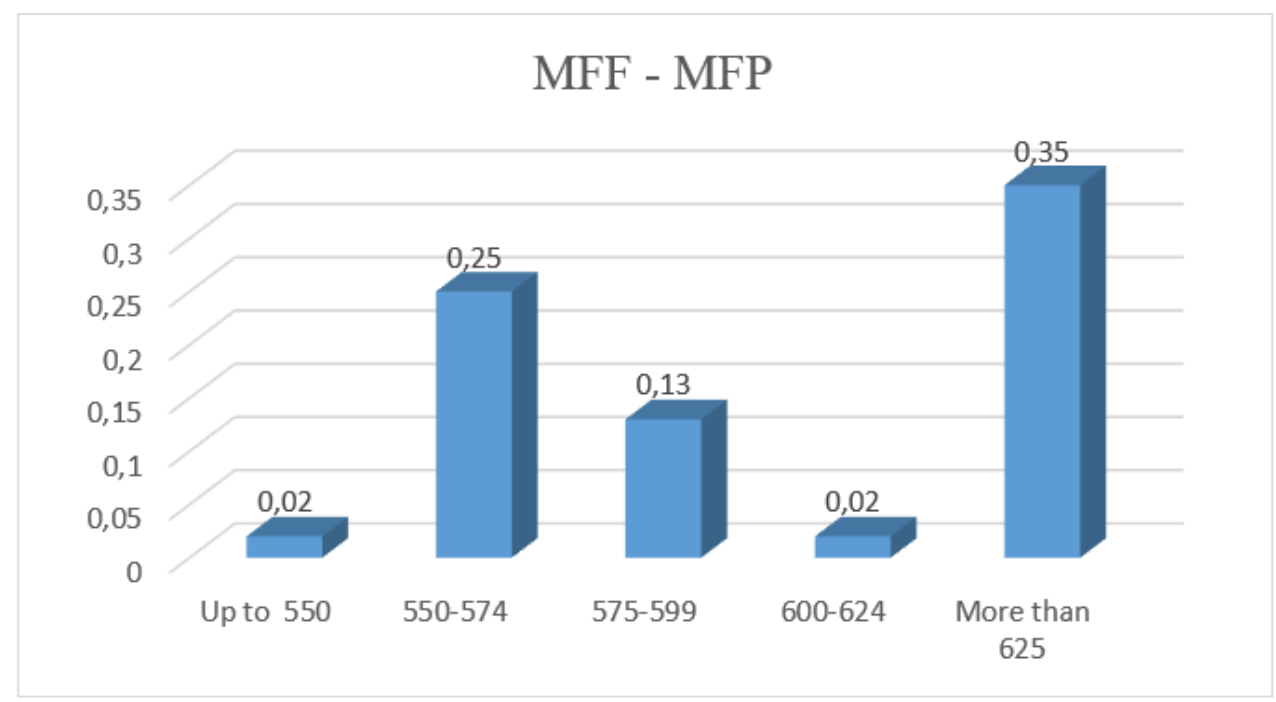

Fig. 5. Correlation coefficients of milk quality indicators.

When carrying out selection and breeding work in a herd, it is possible to select stud bulls for both group and individual selection according to one of the milk quality indicators, which will improve the other trait. 
Influence evaluation of first heifers' live weight on their productive qualities showed that its rise allows increasing the cow productivity but leads to a decrease in milk quality indicators and cannot serve as a trait for selection and breeding since there is a negative correlation with milk yield. Such data are confirmed by the studies of the following authors - N.V. Bogolyubova, V.P. Korotky, A.S. Zenkin, V.A. Ryzhov, N.P. Buryakov [23,24], Mymrin V and Loretts O [21], O V Gorelik, O E Lihodeevskaya, N N Zezin, M Ya Sevostyanov and O I Leshonok [25-27].

\section{Conclusion}

Based on the foregoing, it can be concluded that the farm uses large, highly productive holsteinized Russian Black Pied cattle of the Ural type. An increase in live weight to $625 \mathrm{~kg}$ leads to an increase in milk yield, which negatively correlates with MFF and MFP in cow's milk.

\section{References}

1. O. Gorelik, M. Rebezov, A. Gorelik, S. Harlap, I. Dolmatova, T. Zaitseva, N. Maksimuk, N. Fedoseeva and N. Novikova, International Journal of Innovative Technology and Exploring Engineering 8(7), 559-62 (2019)

2. O. Gorelik et al., International Journal of Pharmaceutical Research (2019) Doi: 10.31838/ijpr/2019.11.01.133

3. O. Gorelik et al. Annual Research \& Review in Biology 18(4), 1-5 (2017) DOI: 10.9734/ARRB/2017/36937

4. A. Belookov, O. Belookova, V. Zhuravel, S. Gritsenko, I. Bobyleva, E. Ermolova, S. Ermolov, Y. Matrosova, M. Rebezov and E. Ponomarev, International Journal of Engineering and Advanced Technology 8 (4), 1058-61 (2019)

5. F. Khaziakhmetov et al., Research Journal of Pharmaceutical, Biological and Chemical Sciences 9(3), 866-70 (2018) WOS:000438847100113

6. F. Khaziakhmetov, A. Khabirov, M. Rebezov, A. Basharov, I. Ziangulov and E. Okuskhanova, International Journal of Veterinary Science, 7 (4), 178-81 (2018)

7. F. Smolnikova, Z. Moldabayeva, M. Klychkova, O. Gorelik, R. Khaybrakhmanov, I. Mironova, A. Kalimullin and G. Latypova, International Journal of Innovative Technology and Exploring Engineering, 8 (7), 670-72 (2019)

8. N. Chernopolskaya, N. Gavrilova, M. Rebezov, S. Harlap, A. Nigmatyanov, G. Peshcherov, T. Bychkova, K. Vlasova and I. Karapetyan, International Journal of Pharmaceutical Research, 11 (1), 545-50 (2019) DOI: 10.35940/ijrte.B3158.078219

9. N. Chernopolskaya, N. Gavrilova, M. Rebezov, I. Dolmatova, T. Zaitseva, Y. Somova, M. Babaeva, E. Ponomarev and O. Voskanyan, International Journal of Engineering and Advanced Technology, 8 (4), 40-45 (2019) DOI: 10.35940/ijrte.B3158.078219

10. N. Gavrilova, N. Chernopolskaya, M. Rebezov, D. Moisejkina, I. Dolmatova, I. Mironova, G. Peshcherov, O. Gorelik and M. Derkho, International Journal of Recent Technology and Engineering, 8 (2), 2718-22 (2019) DOI: 10.35940/ijrte.B3158.078219

11. N. Gavrilova, N. Chernopolskaya, M. Rebezov, E. Shchetinina, I. Suyazova, S. Safronov, V. Ivanova and E. Sultanova, Journal of Critical Reviews, 7(4), 233-36 (2020) DOI: $10.31838 /$ jcr.07.04.43

12. M. Temerbayeva et al., Annual Research \& Review in Biology 23(6), 1-7 (2018) DOI: 
10.9734/arrb/2018/38800

13. M. Temerbayeva et al., Research journal of pharmaceutical biological and chemical sciences, 9 (1), 291-95 (2018)

14. A. Serikova, F. Smolnikova, M. Rebezov, E. Okuskhanova, M. Temerbayeva, O. Gorelik, S. Kharlap, Sh. Baitukenova, S. Baitukenova and Y. Tumbasova, Research Journal of Pharmaceutical, Biological and Chemical Sciences, 9 (4), 495-500 (2018) WOS:000438848100062

15. F. Smolnikova, S. Toleubekova, M. Temerbayeva, E. Cherkasova, O. Gorelik, S. Kharlap, M. Derkho, M. Rebezov and I. Penkova, Research Journal of Pharmaceutical, Biological and Chemical Sciences, 9 (3), 1003-08 (2018) WOS:000438847100131

16. N. Kuramshina, M. Rebezov, E. Kuramshin, L. Tretyak, G. Topuria, D. Kulikov, A. Evtushenko, S. Harlap and E. Okuskhanova, International Journal of Pharmaceutical Research, 11 (1), 1301-05 (2019) DOI: 10.21668/health.risk/2019.2.04.eng

17. E. Skvortsov, O. Bykova, V. Mymrin, E. Skvortsova, O. Neverova, V. Nabokov and V. Kosilov, The Turkish Online Journal of Design Art and Communication 8(SMRCHSPCL), 291-99 (2018)

18. V. Mymrin and O. Loretts, Proceedings of the International Scientific and Practical Conference (ISPC 2019) Advances in Intelligent Systems Research, 511-514 (2019)

19. S. Gridina, V. Gridin and O. Leshonok, Advances in Engineering Research, 253-256 (2018)

20. N. Bogolyubova, V. Korotky, A. Zenkin, V. Ryzhov and N. Buryakov, OnLine Journal of Biological Sciences, 17(2), 121-27 (2017)

21. N. Bogolyubova, V. Romanov, V. Korotky, V. Ryzhov and A. Zenkin, Asian Journal of Pharmaceutical and Clinical Research, 10 (10), 117-20 (2017)

22. O.V. Gorelik et al., IOP Conf. Ser.: Earth Environ. Sci., 548, 082009 (2020) doi:10.1088/1755-1315/548/8/082009

23. O.V. Gorelik et al., IOP Conf. Ser.: Earth Environ. Sci. (2020) /10.1088/1755$1315 / 548 / 8 / 082013$

24. O. Gorelik et al., AIP Conference Proceedings, 2207, 020012 (2020) doi $10.1063 / 5.0000317$ 